\title{
DURABILITY AND STRENGHT PROPERTIES OF TRIPLOCHITON SCLEROXYLON WOOD TREATED WITH THEVITIA PERUVIANA SEED OIL AFTER FUNGAL ATTACK
}

\author{
Adebawo FG \\ Federal College of Forestry, Jericho Hill, Ibadan, PMB 5087 \\ adebawofunke@yahoo.com
}

Submitted April 2019; accepted July 2019

\begin{abstract}
The effect of Thevitia peruviana seed oil treatment on weight loss and compressive strength of decayed sap wood of Triplochiton scleroxylon was investigated. The phytochemical analysis of methanolic extracted T. peruviana seed oil was determined qualitatively and quantitatively after which five concentration levels $(0,25,50,75$ and $100 \%$ ) were prepared. The treated and untreated (control) samples were inoculated with Pleurotus ostreatus and Fibroporia vaillantii for 14 weeks and their weight loss and maximum compressive strength (MCS//) were determined. Data obtained were analysed using Analysis of Variance at $\alpha_{0.05}$. The phytochemical analysis showed that saponins, flavonoid, steroid, terpenoids and coumarin were present. Untreated samples gave weight loss of 42.67 and $50.05 \%$ for $P$. ostreatus and F. vaillantii respectively while the lowest weight losses of 15.09 and $13.93 \%$ were observed in specimen treated with $100 \%$ concentration level of oil for P. ostreatus and F. vaillantii respectively. The maximum compressive strength of 9.25 and $8.93 \mathrm{~N} \mathrm{~mm}^{-2}$ for untreated samples and highest maximum compressive strength of 16.39 and $15.42 \mathrm{~N} \mathrm{~mm}^{-2}$ for treated samples were observed in specimen exposed to $P$. ostreatus and F. vaillantii, respectively. All results showed that $100 \%$ concentration level of oil extract was effective in protecting T. scleroxylon wood against fungal decay.
\end{abstract}

Keywords: Maximum compressive strength, phytochemical analysis, seed oil extract, wood decay, weight loss

\section{INTRODUCTION}

Wood is a natural product, which is one of the components of biodiversity that serves many functions. The mechanical properties of wood have made it useful in variety of ways such as in building, structure, furniture, tools, vehicles and decorative objects. In Nigeria, wood has always been a dominant material for both domestic and industrial use; more than $80 \%$ of timber production in Nigeria is utilised for construction purpose. Wood provides raw materials for building and construction of houses, doors, windows, shops, schools, churches, furniture and agricultural implements for farmers (Okonkwo et. al. 2016)

Wood is a durable material, however its susceptibility to biological decay is a challenge when logs, sawn products or final products are not stored, handled or designed properly. This decay causes wood to become structurally unreliable even before the biological decay of wood becomes visually obvious. In the early stage of wood decay, serious strength losses can occur before the decay is even detected.
Strength properties related to sudden loads, such as toughness or impact bending, are most sensitive to decay. When affected by incipient decay, unseasoned wood may become discolored, however it is harder to detect on dry wood. The advanced stages of wood decay are easier to detect. Decayed wet wood will break across the grain, whereas sound wood will splinter (McGrawHill 2014).

Wood preservation industries across the globe produced many effective synthetic chemicals that help in protecting wood products under different service conditions against deteriorating agents for many years. However, they are costly and their effect on the environment is toxic and harmful. The conventional wood preservatives used to protect wood from insects and microorganisms damage are presently a major concern to human health and environment. Although, these conventional wood preservatives are effective against bio-deterioration agents, they are costly, toxic and hazardous to the environment (Venmalar 2017). Consequently, there has 
been a search for wood preservatives that are less expensive, non-toxic and less harmful to the environment. Recently, research focus has been on the use of plants and their by-products to preserve wood from deteriorating agents, including fungi and termites, because plants are environmentally friendly and are effective in the control of these organisms. Hence, increasing interest in the development of plant materials as an alternative to chemical pesticides has emerged (Ajala et al. 2012, Adenaiya et al. 2016).

Thevetia peruviana is an ever-green ornamental dicotyledonous shrub that belongs to the Apocyanaceae family (Sahoo et al. 2009). It is commonly found in the tropics and sub-tropics but it is native to Central and South America and Mexico. The fruit contains between one to four seeds in its kernel, and milky sap consisting of a compound called theventin that is used as a heart stimulant (Kannah 1990). Thevetia peruviana seed is very rich in oil; the oil yield in the kernel is as high as $62.14 \%(\mathrm{w} / \mathrm{w})$, while other part of the fruit bears negligible amount of oil, and due to its oil availability the seeds may be used for bio-diesel (Sahoo et al. 2009). Thevetia peruviana seed oil has been reported to possess anti-fungi, anti-termite and anti-bacteria properties (Kareru et al. 2010 and Radheykant et al. 2012). Despite the antifungi and anti-termite properties of the seed oil, no report is found on its efficacy in wood preservation. Hence, this study was carried out to investigate the effect of $T$. peruviana seed oil treatment on the durability and strength properties of Triplochiton scleroxylon wood after decay. Triplochiton scleroxylon is recognised as a very important source of timber for export due to its various uses such as in boat and ship building, boxes and crates, cabinet making, plywood, furniture components, furniture and interior construction (Orwa et al. 2009). Despite these uses the species is susceptible to insect and fungal attack. Hence, there is a need to preserve the wood to widen the scope of its utilisation.

\section{MATERIALS AND METHODS}

\section{Preparation of wood samples}

Wood discs at breast height of T. scleroxylon were removed from felled tree samples from Omo Forest Reserve, Ogun State, Nigeria. The sapwood from the disc was removed and cut into samples measuring $20 \times 20 \times 60 \mathrm{~mm}$ according to British Standard (1957) test method for solid wood. One hundred clear wood specimen with no defects were selected and sanded with sandpaper to eliminate rough edges. The initial weight of the samples was taken and then oven dried for 24 hours at temperature of $103 \pm 2{ }^{\circ} \mathrm{C}$ to constant weight.

\section{Method of extraction and dilution}

Thevetia peruviana seeds were collected at Jericho GRA, Ibadan, Nigeria. The seeds were removed from the kernel and air dried to reduce its moisture content. The seeds were ground, weighed, packed and put into a thimble of soxhlet apparatus which was run for 6 hours using methanol as a solvent. The oil obtained was stored in a sterilised bottle and refrigerated before its usage. Thevetia peruviana seed oil extract was made into five different concentrations using kerosene as a diluent. Volume by volume method was adopted i.e. $20 \mathrm{ml}$ of oil and $80 \mathrm{ml}$ of kerosene equal $20 \%$ concentration. Hence, 0 , 25, 50,75 and $100 \%$ was used for this experiment, in accordance with Ajala (2014). Each of the diluted concentration had four replicates of wood samples. The wood samples were immersed into different concentrations for 24 hours, then they were removed, air-dried and the final weight was taken.

\section{Phytochemical analysis of Thevetia peruviana seed oil extract}

Phytochemical screening of Thevetia peruviana seed oil was accordance to the standard procedure by Brain and Turner (1975). The seed oil extract was subjected to phytochemical screening to identify the presence of alkaloids, tannins, flavanoids, fats, saponins, phenolic compounds, steroids and terpenoids.

\section{Inoculation and incubation of test fungi}

The inoculums of white rot fungi (Pleurotus ostreatus) and brown rot fungi (Fibroporia vaillantii) were cultured using potato dextrose agar as a culturing medium. The control wood blocks and test blocks treated at each concentration of the seed oil extract were placed in McCartney bottles containing actively growing test fungi. All test blocks were exposed to the fungi at 
room temperature $\left(27 \pm 2{ }^{\circ} \mathrm{C}\right)$ for 14 weeks. At the end of the incubation period, the blocks were removed from the culture bottles and the adhering mycelia were carefully cleaned off the wood surface (Adebawo 2017).

\section{Determination of weight loss}

The wood blocks, after exposure to fungal attack, were oven-dried at $103{ }^{\circ} \mathrm{C}$ for 24 hours and then re-weighed to determine the weight loss. The percentage weight loss was estimated using equation 1.

$$
\text { Weight loss }(\%)=\frac{\mathrm{T}_{1}-\mathrm{T}_{2}}{\mathrm{~T}_{1}} \times 100
$$

where $T_{1}=$ weight of wood specimen and remaining preservative after conditioning and before exposure to the test fungi $(\mathrm{g})$ and $\mathrm{T}_{2}=$ weight of the wood specimen after test and after final conditioning $(\mathrm{g})$.

\section{Determination of maximum compressive strength}

A Hounsfield tensometer was used to determine the maximum compressive strength (MCS//) parallel to grain of each wood blocks exposed to fungi attack according to ASTM 143-94 (2000). All the test blocks were conditioned before the test. Load was applied at the rate of $0.01 \mathrm{~mm}$ per second and the corresponding force at the point of failure was taken directly on the scale and recorded.

\section{Statistical analysis}

The data obtained were analysed using Analysis of Variance (ANOVA). Means were separated with the aid of Duncan Multiple Range Test at $5 \%$ level of significance.

\section{RESULTS AND DISCUSSION}

\section{Phytochemical analysis}

The phytochemical analysis of T. peruviana seed oil extract was determined qualitatively and quantitatively, and the results are presented in Table 1. Phytochemicals generally exert their antimicrobial activities through different mechanisms and are known to be biologically active because they protect the plants against infections (Scalbert 1991). From the present study, it was observed that saponins, flavonoid, steroid, terpenoids and coumarin were present in the extract while tannins, phlobatanins, anthocyanin and anthraquinones were absent. This agrees with the findings of Dooh et al. (2014), who reported similar results in the qualitative analysis of $T$. peruviana methanolic extract. Quantitatively, alkaloids had the highest value in the seed oil extract, and it has been reported to act as a deterrent against microbial and insect attacks (Macel 2011).

Alkaloids are organic heterocyclic nitrogen compounds that are basic-forming water-soluble salts. They contain nitrogen, which is usually derived from an amino acid. Alkaloids have been reported to have antimicrobial properties which

Table1 Phytochemical analysis of Thevetia peruviana seed oil extract

\begin{tabular}{lcc}
\hline Phytochemicals & Qualitative & Quantitative $\left(\mathrm{mg} \mathrm{g}^{-1}\right)$ \\
\hline Saponins & + & 120.6 \\
Flavonoids & + & 116.2 \\
Tannins & - & - \\
Alkaloids & + & 140.94 \\
Steroids & + & - \\
Terpenoids & + & 82.36 \\
Phlobatanins & - & - \\
Anthocyanin & - & - \\
Anthraquinones & - & - \\
Coumarin & + & Trace \\
\hline
\end{tabular}

$+=$ phytochemicals are present,$-=$ phytochemicals are absent 
are effective against fungal growth (Carson \& Hammer 2010). Phytochemical screening of $T$. peruviana oil revealed that the main constituent found in higher concentrations were alkaloids (140.94 $\mathrm{mg} \mathrm{g}^{-1}$ ) which could have contributed to the reduced weight loss of the wood samples treated with the oil after fungal attack.

Saponins found in the oil were also of higher concentration (120 $\left.\mathrm{mg} \mathrm{g}^{-1}\right)$, next to alkaloids. Saponins are a major family of secondary metabolites that occur in a wide range of plant species (Osbourn 1996). These compounds are present in plants and are reported to be involved in plant disease resistance because of their wellknown antimicrobial activity (Elisa et al. 2007). Saponins has been characterised and reported to act as a deterrent for biological activity against insects (Macel 2011).

Flavonoids are also found in the oil at a high concentration of $116.2 \mathrm{mg} \mathrm{g}^{-1}$, next to saponins. Flavonoids are phenolic structures found abundantly in photosynthesising cells. Esmaeili et al (2013) reported that they are secondary metabolites that provide UV protection and color to almost all terrestrial plants and fruits. They are usually found in many common edible plant parts such as fruits, vegetables, nuts and seeds. Flavonoid compounds have a structural feature of the 2-phenyl-benzopyrane or flavine nucleus, which consists of two benzene rings linked through a heterocyclic pyrane ring (Savoia 2012, Carson \& Hammer 2010). Flavonoids are important plant components due to their active hydroxyl groups and anti-oxidative properties (Güder et al. 2014). They are known to have antioxidant, anti-inflammatory and antitumor activity. Flavonoid compounds have been reported to inhibit wood decay fungi (Tumen et al. 2013, Li et al. 2014).

Concentration of terpenoids in the oil extract was $82.36 \mathrm{mg} \mathrm{g}^{-1}$ which was the lowest concentration of all the phytochemicals present in the oil. Terpenoids are reported to be used as flavouring agents, insect repellents, fungicides and for medicinal purposes. The research conducted by Barbehenn and Constabel (2011) confirms that flavonoids, steroids and terpenoid have antioxidant and antimicrobial properties, which could be attributed to the antifungal activity exerted by the oil against wood decay.

\section{Weight loss}

The weight loss of T. scleroxylon wood species is presented in Figure 1. The mean weight loss due to $P$. ostreatus attack ranged from $15.09-42.67 \%$. Control had the highest mean weight loss of $42.67 \%$, while $100 \%$ concentration had the least weight loss of $15.09 \%$. The mean weight loss due to $F$. vaillantii attack ranged from $13.93-50.05$ $\pm 2.86 \%$. Control had the highest mean weight loss of $50.05 \%$, while $100 \%$ concentration had the least weight loss of $13.93 \%$.

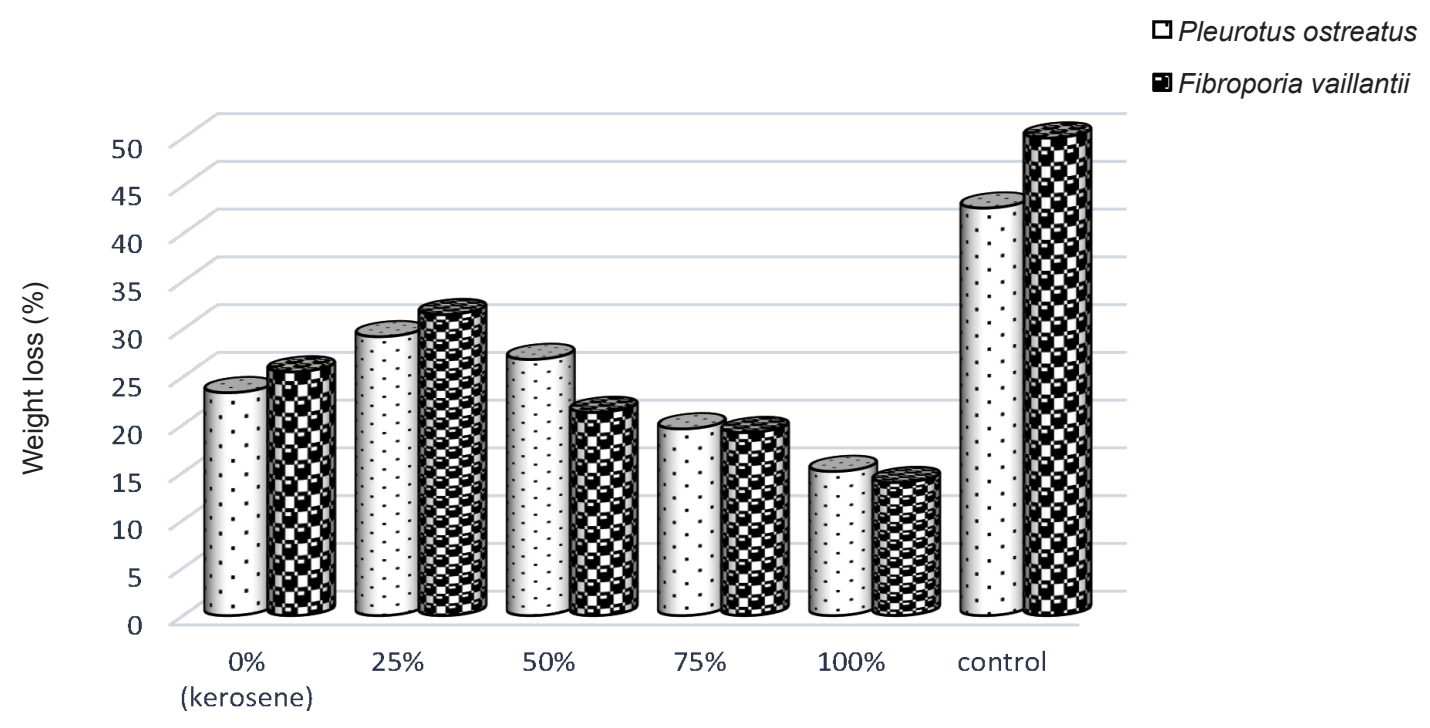

Concentration level

Figure 1 Weight loss of Triplochiton scleroxylon wood after fungi attack 
The ANOVA showed that there was no significant difference between the two fungi, $P$. ostreatus and $F$. vaillantii, but there was significant difference among the treatments for weight loss (Table 2). The mean weight loss due to $P$. ostreatus attack on T. scleroxylon wood increased from $0 \%$ (only kerosene) to $25 \%$ concentration and decreased from 50-100\% concentration, while control had the highest mean weight loss. The mean weight loss due to $F$. vaillantii attack followed the same trend.

The follow up results showed no significant difference between the white and brown rot fungal attack (Table 4). A similar pattern of weight loss was observed for both white rot fungi and brown rot fungi with a decreasing rate from control samples and $25 \%$ concentration to $100 \%$ concentration. The $0 \%$ (only kerosene) concentration exhibited a reduced weight loss compared to the control samples. This may be due to the fact that diluent (kerosene) was able to give temporary inhibition to fungal decay but evaporated with time. This observation is consonant with the findings of Adenaiya et al. (2016) who reported a decrease in $0 \%$ concentration compared to control samples for wood samples of Pinus caribaea treated with castor seed oil.
From the study findings, it is clear that fungal resistance was enhanced at higher concentrations of the oil, and the effect of the oil extract was maximised at $100 \%$ concentration. This could be attributed to the antifungal properties of the phytochemicals present in the oil. The decrease in weight loss at higher concentrations is in line with the work of Emerhi et al. (2015) who reported that weight loss of T. scleroxylon wood reduced with increased concentrations, when treated with Lagenaria breviflora fruit pulp juice. However it is at variance with the findings of Osman et al. (2007) who reported that weight loss increased with the increase in concentrations, when inoculated Scots pine (Pinus sylvestris) with Postia placenta and Trametes versicolor, treated with poisonous Sternbergia candidum extract.

\section{Maximum compressive strength parallel to grain}

Rot initially affects the ability of wood to withstand impacts which is followed by decrease in strength properties. A wood that shows visible signs of decay most likely has greatly reduced strength values. There is no method known to estimate strength loss through visual inspection of decayed

Table 2 Analysis of variance of weight loss of Triplochiton scleroxylon wood after fungi attack

\begin{tabular}{lccccc}
\hline Source of variation & DF & SS & MSS & F & Significance \\
\hline Fungi & 1 & 7.513 & 7.513 & 0.387 & $0.538^{\text {ns }}$ \\
Concentration & 5 & 4914.87 & 982.974 & 50.577 & $0.000^{*}$ \\
Fungi * Concentration & 5 & 186.085 & 37.217 & 1.915 & $0.116^{\text {ns }}$ \\
Error & 36 & 699.663 & 19.435 & & \\
Total & 47 & 5808.13 & & & \\
\hline
\end{tabular}

$\mathrm{DF}=$ degree of freedom, $\mathrm{SS}=$ sum of squares, MSS = mean sum of squares, $\mathrm{F}=$ distribution, $* \mathrm{p}<0.05$

Table 3 Analysis of variance of compressive strength of Triplochiton scleroxylon wood after fungi attack

\begin{tabular}{lrrrrc}
\hline Source of variation & DF & \multicolumn{1}{c}{ SS } & MSS & \multicolumn{1}{c}{ F } & Significance \\
\hline Fungi & 1 & 2.808 & 2.808 & 2.084 & $0.158^{\mathrm{ns}}$ \\
Concentration level & 5 & 638.004 & 127.601 & 94.689 & $0.000^{*}$ \\
Fungi * Concentration level & 5 & 26.518 & 5.304 & 3.936 & $0.006^{*}$ \\
Error & 36 & 48.513 & 1.348 & & \\
Total & 47 & 715.843 & & & \\
\hline
\end{tabular}

$\mathrm{DF}=$ degree of freedom, $\mathrm{SS}=$ sum of squares, MSS = mean sum of squares, $\mathrm{F}=$ distribution, $* \mathrm{p}<0.05$ 
Table 4 Follow up test for weight loss and maximum compressive strength parallel to grain

\begin{tabular}{ccc}
\hline Concentration levels & Weight loss $(\%)$ & Compressive strength $(\%)$ \\
\hline $0 \%$ & $24.43^{\mathrm{c}}$ & $15.9^{\mathrm{a}}$ \\
$25 \%$ & $30.35^{\mathrm{b}}$ & $11.94^{\mathrm{b}}$ \\
$50 \%$ & $24.04^{\mathrm{c}}$ & $16.95 \mathrm{~b}^{\mathrm{c}}$ \\
$75 \%$ & $19.35^{\mathrm{d}}$ & $17.79^{\mathrm{c}}$ \\
$100 \%$ & $14.51^{\mathrm{e}}$ & $19.84^{\mathrm{d}}$ \\
control & $46.36^{\mathrm{a}}$ & $9.09^{\mathrm{a}}$ \\
\hline
\end{tabular}

Mean with the same alphabet are not significantly different from each other at $\alpha=0.05$

wood. Strength loss in wood after fungal decay can only be determined through mechanical test, and in this study, MCS// parallel to grain was used. The result of MCS/ / parallel to grain of $T$. scleroxylon wood species exposed to $P$. ostreatus and $F$. vaillantii is presented in Figure 2. The mean values of MCS// after white rot fungi attack ranged from $9.25 \pm 0.51-18.63 \pm$ $0.94 \mathrm{~N} \mathrm{~mm}^{-2}$. Control had the least MCS// of 9.25 $\pm 0.51 \mathrm{~N} \mathrm{~mm}^{-2}$, while $100 \%$ concentration had the highest MSC// of $18.63 \pm 0.94 \mathrm{~N} \mathrm{~mm}^{-2}$. The mean values of MCS/ / after brown rot fungi attack ranged from $8.93 \pm 0.81-21.05 \pm 1.97 \mathrm{~N} \mathrm{~mm}^{-2}$. Control had the lowest MCS//of $8.93 \pm 0.81 \mathrm{~N} \mathrm{~mm}^{-2}$, while $100 \%$ concentration had highest MCS// of $21.05 \pm 1.97 \mathrm{~N} \mathrm{~mm}^{-2}$. The results show that the average MCS/ / for white rot fungi is greater than that of brown rot, but from ANOVA there is no significance difference between the two fungi. This indicates that both fungi exhibited the same effect on wood. However it is at variance to the work of Adenaiya et al. (2016) who reported that the average MCS / / for wood samples exposed to $S$. rolfsii, white rot fungi, was higher than those exposed to G. lucidum, brown rot fungi.

However, the ANOVA showed that there is a significant difference among the treatments for MCS/ / on wood at 5\% level of significance. The results revealed that $100 \%$ concentration was most effective in reducing the mechanical damage to wood due to fungi infestation, when compared with the mean values of sound T. scleroxylon wood, ranging between 24.68$26.34 \mathrm{~N} \mathrm{~mm}^{-2}$. This is in accordance with the findings of Olajuyigbe et al. (2010) who reported that MCS// of T. scleroxylon wood ranged from 20.55-28.95 N mm${ }^{-2}$ when treated with Tectona grandis heartwood extract and Cuprinol clear solution and subjected to white rots decay of Lentinus subnudus and Pleurotus squarrosullus. However, this observation is contrary to the report of Zhong et al. (2007) where it was reported that wood exposed to brown rot fungus had lower MCS// than those exposed to white rot fungus. Several studies have equally reported higher reduction in wood strength for brown rot than white rot fungi (Ajala et al. 2014, Adenaiya et al. 2016). This shows that out of the three main components of wood, that is, cellulose, hemicelluloses and lignin, the initial loss in strength from early brown-rot decay is due to the attack on hemicellulose, and then the cellulose. Low weight loss in decayed wood is due to significant reductions in the degree of polymerisation of holocellulose (McGraw-Hill 2014).

\section{CONGLUSION}

The study showed the efficacy of $T$. peruviana seed oil treatment on weight loss and MCS// of T. scleroxylon wood after fungi decay. The phytochemical screening of the oil showed that active compounds such as alkaloids, saponins, flavonoids, terpenoids and coumarin are present. These have been reported to have antimicrobial properties which may be responsible for preventing both brown and white fungi attack on treated wood, thereby reducing weight loss of the wood and preventing mechanical damage on wood. The untreated specimens showed higher weight loss and lower MCS/ / compared to their treated counterparts. Therefore, it is concluded that $T$. peruviana seed oil extract is effective in improving the resistance of $T$. scleroxylon wood against fungi attack. 


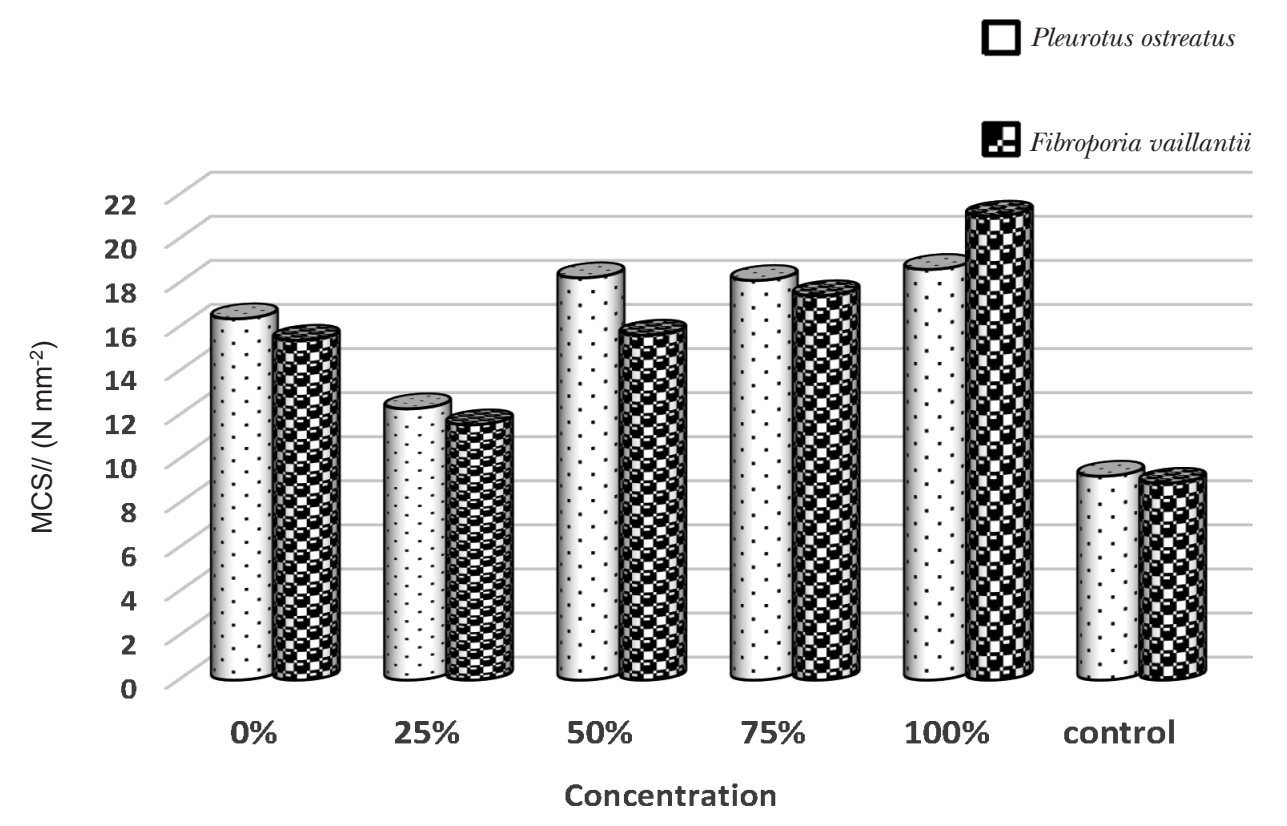

Figure 2 Compressive strength parallel to grain of Triplochiton scleroxylon wood after fungi attack

\section{REFERENCES}

Adebawo FG. 2017. Technical properties of acetylated Triplochiton scleroxylon K. Schum wood. PhD thesis, Department of Agriculture and Forestry, University of Ibadan, Ibadan.

Adenaiya OA, Ogunsanwo YO \& Onakpoma I. 2016. Weight loss and compressive strength of castor oil-treated Pinus caribaea (Morelet) wood exposed to fungi. ProLigno 12: 41-52.

ajala OO, Adebawo FG \& Olayiwola YB. 2012. Potential of Moringa oleifera (Lam) seed oil as a bio-preservative agent against fungi attack an Aningeria robusta wood (A. Chev). Pp 186-190 in Onyekwelu BO et al. (eds) De-Reservation, Encroachment and Deforestation: Implications for the Future of Nigerian Forest Estate and Carbon Emission Reduction. Proceedings of the $3^{\text {rd }}$ Biennial National Conference of the Forest and Forest Products Society. 3-6 April, 2012, Ibadan.

ajala OO, Adebawo FG, Yekeen OM \& Owoade OD. 2014. Potentials of seed oil extract of Azadirachta indica (A. JUSS) as preservative against wood-decaying fungi of Aningeria robusta (A. CHEV.). Pp 588-595 in Ogunsanwo et al. (eds) Sudano-Sahelian Landscape and Renewable Natural Resources Development in Nigeria. Proceedings of the $37^{\text {th }}$ Annual Conference of the Forestry Association of Nigeria. 9-14 November, 2014, Minna, Niger State.

AJALA OO. 2014. Potentials of heartwood extract of Gliricidia sepium (Jacq.) Steud as preservative against wood decaying Lentinus sajor-caju and Trichoderma viride. $\mathrm{PhD}$ thesis, Department of Agriculture and Forestry, University of Ibadan, Ibadan.

Astm D 1413. 2000. Standard Test Method of Testing Wood Preservatives by Laboratory Soil-Block Cultures. Annual Book of ASTM Standard, Pennsylvania.
Barbehenn RV \& Constabel PC. 2011. Tannins in plantherbivore interactions. Journal of Phytochemistry 72: 1551-1565.

BRITISH STANDARD 373 (BS 1957): Methods of Testing Small Clear Specimens of Timber. British Standards Institution, London.

BraIn KR \& Tnuner TD. 1975. The Practical Evaluation of Phytopharmaceuticals. $1^{\text {st }}$ edition. WrightScientechnica, Bristol.

Carson CF \& Hammer KA. 2010. Chemistry and bioactivity of essential oils. Pp 203-238 in Thormar H (ed) Lipids and Essential Oils as Antimicrobial Agents. John Wiley \& Sons, New York.

Dooh JPN, Ambang Z, Ewola AT, Heu A, Kosma P, Yalen EJM \& Goghomu RT. 2014. Screening and the effect of extracts of Thevetia peruviana on the development of Colletotrichum gloeosporioides, causal agent of cassava anthracnose disease. Journal of Agricultural Research and Development 4: 054-065.

Elisa B, Giuliano B, Vincenzo A, Behzad Z, Ebrahim S, Felice S \& Virginia L. 2007. Saponins from Allium minutiflorum with antifungal activity. Phytochemistry 68: 596-603.

Emerhi EA, Adedeji GA \& Ogunsanwo OY. 2015. Termites' resistance of wood treated with Lagenaria breviflora B. Robert fruit pulp extract. Nature and Science 13: 105-109.

Esmaeili A, Mousavi Z, Shokrollahi M \& Shafaghat A. 2013. Antioxidant activity and isolation of luteoline from Centaurea behen L. grown in Iran. Journal of Chemistry 2013: 1-5.

GÜder A, Engin MS, Yolcu M \& GÜr M. 2014. Effect of processing temperature on the chemical composition and antioxidant activity of Vaccinium arctostaphylos fruit and their jam. Journal of Food Processing and Preservation. 38: 1696-1704.

Kannah R. 1990. Koels feeding on the yellow oleander. Blackbuck 7: 48. 
Kareru PG, Keriko JM, Kenji GM \& Gachanja AN. 2010. Antitermite and antimicrobial properties of paint made from Thevetia peruviana (Pers.) Schum oil extract. African Journal of Pharmacy and Pharmacology 4: 87-89.

Li Q, Wang XX, Lin JG, Liu J, Jiang MS \& Chu LX. 2014. Chemical composition and antifungal activity of extracts from the xylem of Cinnamomum camphora. Bioresources 9: 2560-2571.

MACEL M. 2011. Attract and deter: a dual role for pyrrolizidine alkaloids in plant-insect interactions. Phytochemistry Review 10: 75-82.

Mcgraw-Hill. 2014: Yearbook of Science and Technology. McGraw-Hill Education, New York.

Okоnkwo EE, Ukaegbu MO \& Eusi AP. 2016. A Documentation of Some Traditional Aspects of Wood Consumption in Anaocha, Nigeria. SAGE Open April-June 2016: $1-8$.

Olajuyigbe SO, Ogunsanwo OY \& Adegeye AO. 2010. Compressive strength in Heartwood Extract of Teak (HWE) treated hardwoods after exposure to white rot attack International Journal of Biological and Chemical Science 4: 571-578.

Orwa C, Mutua A, Kindt R, Jamnadass R \& Anthony S. 2009. Agroforest Tree Data Base: A Tree Reference and Selection Guide Version 4.0. World Agroforestry, Nairobi.

Osbourn AE. 1996. Saponins and plant defense - a soap story. Trends in Plant Science 1: 4-9.

Osman G, Ramazan M, Emin MD, Ertan O, Melda AC \& Ferah Y. 2007. Introduction and evaluation of the wood preservative potentials of the poisonous Sternbergia candidum extracts. African Journal of Biotechnology 6: 982-986.

Radheykant S, Priyanka S \& Vipin KS. 2012. Antimicrobial Properties of Thevetia peruviana. Department of Chemistry, Government Post Graduate College, Alwar.

Sahoo NK, Subhalaxmi P, Pradhan R \& Nai SN. 2009. Physical properties of fruit and kernel of T. peruviana: A potential biofuel plant. International Agrophysics 23: 199-204.

SAVOIA D. 2012. Plant-derived antimicrobial compounds: alternatives to antibiotics. Future Microbiology 7: 979-990.

SCAlBert A. 1991. Antimicrobial properties of tannins. Phytochemistry 30: 3875-3883.

Tumen I, Eller FJ, Clausen CA \& Teel JA. 2013. Antifungal activity of heartwood extracts from three Juniperus species. Bioresources 8: 12-20.

Venmalar D. 2017. Screening of Oils of Pongamia pinnata Linn., Jatropha curcas Linn. and Simarouba glauca D.C. for developing eco-friendly wood preservatives. Pp 261-268 in PANDEY K et al (eds) Wood is Good. Springer, Berlin.

Zhong Y, Zhehui J, Chung YH \& Todd FS. 2007. Strength reduction in slash pine (Pinus elliotii) wood caused by decay fungi. Pp 383-390 in Chung YH et al. (eds) Advanced Biomass Science and Technology for Bio-Based Products. Chinese Academy of Forestry and USDA Forest Service, Southern Research Station. 23-2 May 2007, Beijing 